\title{
External injuries of Morelet's crocodile Crocodylus moreletii in Campeche, Mexico
}

\author{
Sergio E. Padilla ${ }^{1,3}$, Manuel Weber ${ }^{2, *}$ \\ ${ }^{1}$ Centro de Estudios de Desarrollo Sustentable y Aprovechamiento de la Vida Silvestre, Universidad Autónoma de Campeche. \\ Avenida Héroe de Nacozari S/N, CP 24072, San Francisco de Campeche, Campeche, Mexico \\ ${ }^{2}$ El Colegio de la Frontera Sur-ECOSUR, Departamento de Conservación de la Biodiversidad, Avenida Rancho Polígono 2A, \\ Ciudad Industrial Lerma, 24500 Campeche, Mexico \\ ${ }^{3}$ School of Natural Resources and Environment, 103 Black Hall, PO Box 116455, University of Florida, Gainesville, \\ Florida 32611, USA
}

\begin{abstract}
Analysis of external injuries in captive and free-ranging Morelet's crocodiles Crocodylus moreletii was performed in the northern wetlands of Campeche, Mexico. From March to September of 2007, a total of 52 free-ranging and 51 captive Morelet's crocodiles were studied. Captive crocodiles presented significantly more injuries. Sixteen free-ranging crocodiles presented some type of lesion, mostly superficial abrasions. Nineteen captive crocodiles presented lesions, mostly incisions from agonistic interactions. Overall, the injuries with highest prevalence were the incisions. The tail was the most frequently injured body region. Injuries were more common in adults than in other size classes. Conversely, the presence of lesions caused by the parasite Paratrichosoma spp. was greater in crocodiles captured in the coastal channels (mangrove habitat). The information presented here is important to understand some of the effects of individual interactions and to foresee and manage the consequences of conservation and management activities of crocodile populations.
\end{abstract}

KEY WORDS: Individual interactions $\cdot$ Free-ranging crocodiles $\cdot$ Lesions $\cdot$ Paratrichosoma

\section{INTRODUCTION}

Crocodiles and alligators have a complex social structure (Garrick et al. 1978). A major characteristic of this population is the existence of dominance hierarchies (Lang 1987). Given the social nature of crocodilians, behavioral exhibitions are interactive (Seebacher \& Grigg 1997). Crocodiles often engage in agonistic interactions, which regularly result in subordinate individuals with wounds being chased away (Lang 1987). Injuries and infected wounds could have a negative effect on the survival, growth and physical condition (e.g. reproductive capacity) of individuals and therefore on the population dynamics (Seijas 2007). The development and implementation of adequate conservation strategies requires understanding the dynamics of the competitive interactions between individuals (Macdonald et al. 2000). This is particularly relevant for species with an ecologic and economic value such as crocodiles and alligators.

In crocodilians, some external parasites have been reported, such as leeches, ticks and nematodes of the genus Paratrichosoma (Webb \& Messel 1977, Webb \& Manolis 1983, Montague 1984, Buenviaje et al. 1998, Moravec \& Vargas-Vázquez 1998, Rainwater et al. 2001, Seijas 2007). The nematode P. recurvum was first reported in Crocodylus moreletii in Yucatán, Mexico (Moravec \& Vargas-Vázquez 1998) and can be found mostly in the ventral region of the animals, causing zigzag tracks on the skin. Montague (1984) suggests that low body weight in $C$. novaeguineae is 
related to the incidence of this parasite. For $C$. moreletii, little information about this parasitic interaction has been documented.

Morelet's crocodiles live in streams, water ponds and interior lagoons on the tropical side of the Gulf of Mexico, from the State of Tamaulipas (northern Mexico) to the Yucatan Peninsula, and in northern Guatemala and Belize (CONABIO 2011). This crocodile reaches a maximum size of 3 to $3.5 \mathrm{~m}$ in length (Alvarez del Toro \& Sigler 2001), and there is no apparent sexual dimorphism. The hide of $C$. moreletii is highly valued in the fur and pelt market, which led to indiscriminate hunting and the reduction of wild populations throughout its range (INE 1999, Padilla \& Perera-Trejo 2010, Zamudio et al. 2011). Currently, C. moreletii is subject to special protection by Mexican and international legislations.

Research on the Morelet's crocodile has focused on population ecology, especially on its distribution, densities and population structure (Platt et al. 1999a, Platt \& Thorbjarnarson 2000, Domínguez-Laso 2005, Cedeño-Vázquez et al. 2006). Studies on injuries and lesions are scarce or nonexistent, in spite of the fact that this species has been bred in captivity in Mexico since the end of the 1960s (Beltrán 1969). For this reason, we performed a descriptive analysis of the external injuries and external parasites of $C$. moreletii (comparing captive and free-ranging animals) in southeastern Mexico.

\section{MATERIALS AND METHODS}

\section{Study area}

Wild crocodiles were randomly captured in the northern coastal wetlands of the state of Campeche, Mexico. This region is characterized by the presence of hammocks (locally known as Petenes), described as islands of forest surrounded by mangroves and salt marshes with freshwater available year-round (CONANP 2006). In 1999, this region was declared as Los Petenes Biosphere Reserve by UNESCO and the Mexican Government, covering 282857 ha of protected area $\left(20^{\circ} 51^{\prime} 35^{\prime \prime} \mathrm{N}, 90^{\circ} 45^{\prime} 15^{\prime \prime} \mathrm{W}\right.$ to $19^{\circ} 49^{\prime} 00^{\prime \prime} \mathrm{N}$, $90^{\circ} 20^{\prime} 00^{\prime \prime} \mathrm{W}$ ). The sampling of the wild population took place in 3 major sites within this wetland ecosystem (Fig. 1): Hampolol, El Remate-Isla Arena streams and Petenes coastal channels (Bocas and Jaina). Ten field trips were performed to observe and capture wild crocodiles.

Captive crocodiles were randomly sampled in the facilities of the Centro de Estudios Tecnológicos del
Mar No. 2 (CETMAR) in the city of Campeche, Mexico. The CETMAR holds around 300 crocodiles ranging from hatchlings to reproductive adults. In order to have a comparable database between captive and free-ranging crocodiles, we examined 51 captive animals from enclosures in CETMAR to match with the 52 crocodiles sampled in the wild.

Free-ranging crocodiles were captured from March to September of 2007, following the method suggested by Woodward \& Marion (1978). This includes the use of spotlights and headlamps from a boat equipped with an outboard motor and/or paddles. Crocodiles were captured using Thompson ${ }^{\circledR}$ snares attached to an aluminum pole. The crocodiles were physically restrained in order to take body measurements and to record external injuries. The sex of crocodiles was determined by examination of the cloacae (Webb et al. 1984). The size classes used to classify individuals as suggested by Platt \& Thorbjarnarson (2000) and CONABIO (2011) were as follows: Class I $(<50 \mathrm{~cm}$, hatchlings), Class II ( $>50$ to $100 \mathrm{~cm}$, juveniles), Class III (>100 to $150 \mathrm{~cm}$, subadults) and Class IV ( $>150 \mathrm{~cm}$, adults).

External standard examination of the crocodiles was implemented. Skin condition, muscle tone, fat deposits, external injuries, eye condition and reaction to light, third eyelid condition, principal joints, as well as a general mouth and cloaca examination was systematically recorded for each crocodile (Huchzermeyer 2003). External injuries were classified according to their type, severity, location and condition (Table 1). Five different types of lesions were defined: (1) incision is a wound created by cutting; (2) laceration is a forceful tearing of the skin; (3) puncture is a hole-shaped wound; (4) bruise is an injury where the skin has not been broken, often as a result of being hit by something; and (5) mutilation is a lesion that results in the absence of a body part (i.e. tail tip, toes). The severity of injuries was assessed according to the depth of the lesion, where injuries that presented exposed muscle were classified as being more severe. The external parasites were

Table 1. External injuries in Crocodylus moreletii reported in this study

\begin{tabular}{|lccc|}
\hline Type of injury & Severity & Location & Condition \\
\hline Incision & Superficial & Dorsal & Recent \\
Laceration & Deep & Ventral & Healing process \\
Puncture & & Head & \\
Bruise & & Trunk & Healed \\
Mutilation & & Tail & \\
& & & \\
\hline
\end{tabular}



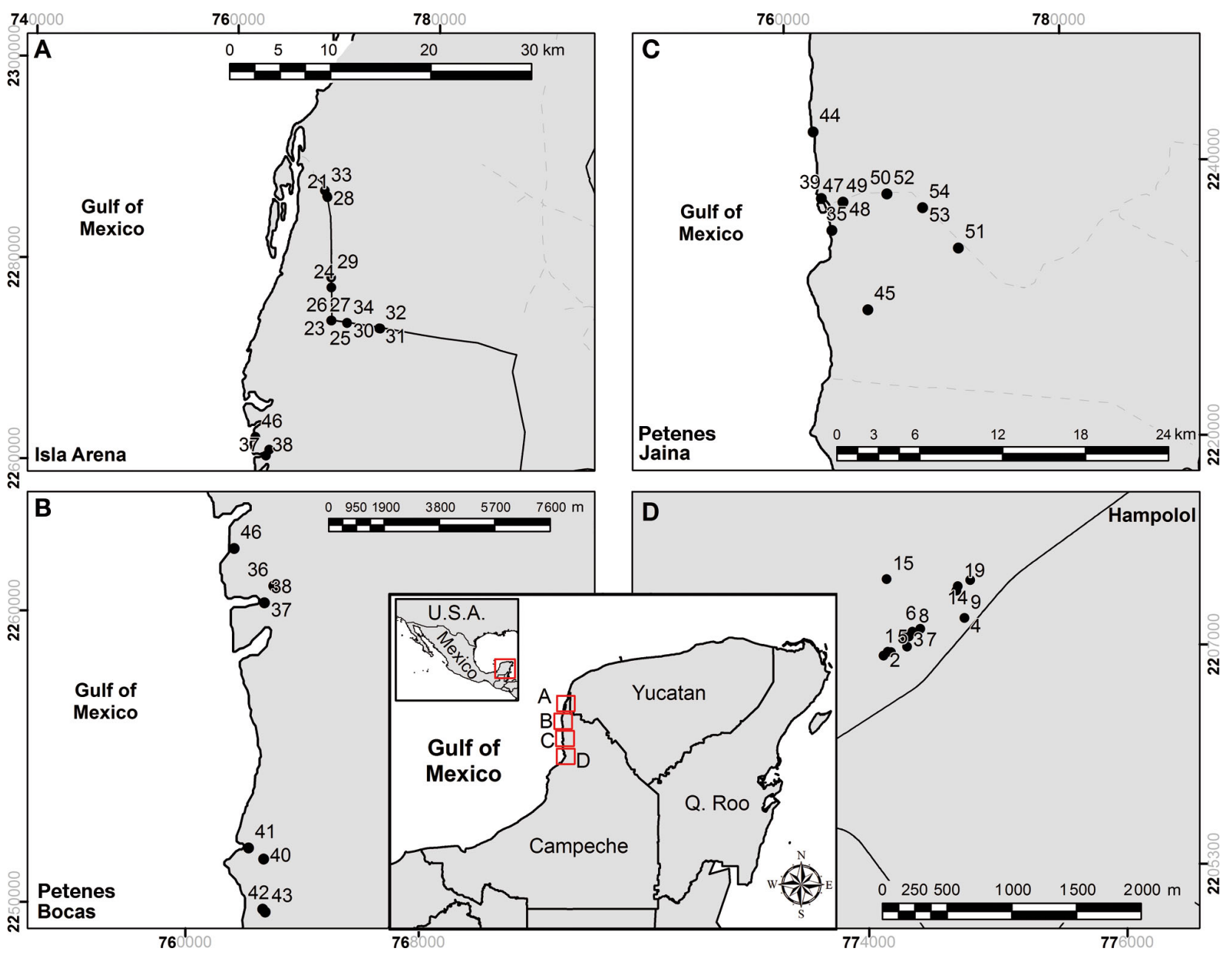

Fig. 1. Sample sites of wild crocodiles in the Los Petenes Biosphere Reserve located in the northern coastal wetlands of the state of Campeche, Mexico. Sites: (A) El Remate-Isla Arena; (B) Bocas; (C) Jaina; (D) Hampolol. (•) Crocodylus moreletii samples. Coordinates are UTM system

recorded according to their type, location and spread $(\%)$ on the body of the crocodile.

A $G$ log likelihood test was performed to analyze the data, looking for differences in observed and expected frequencies (mean prevalence) of external injuries and parasites. Differences in external injuries between captive and free-ranging crocodiles, capture sites, and size classes and sexes were tested. A similar test was performed to look for associations between the presence of parasites and size classes, sex, and body location of external parasites. An ad hoc macro Excel datasheet (Microsoft Office ${ }^{\circledR}$ 2010) was developed for the calculation of the G-test (Fowler et al. 1998, Dytham 2006). The expected frequencies were calculated using a priori (intrinsic) information from the data, since we cannot predict the expected frequencies before the collection of the data and observations (Dytham 2006, McDonald 2014).

\section{RESULTS}

External injuries of 103 Morelet's crocodiles (52 wild and 51 captive) were analyzed. From these, 38 were female, 43 males and 22 could not be sexed due to their immature stage. Sixteen of $52(30 \%)$ of the free-ranging crocodiles and 19 of $51(37 \%)$ of the captive crocodiles presented external injuries, mostly superficial incisions and abrasions. The total number of lesions observed was 70 for captive crocodiles and 31 for the free-ranging crocodiles. The most common injury observed in captivity were incisions (33) both healed and in the processes of healing. Free-living crocodiles presented more bruises (13) than any other injury. For all the pooled sample of crocodiles, the most common injury was incision $(G=23.61$, $\mathrm{df}=4, \mathrm{p}<0.001)$. Injuries were associated with the capture site. Petenes (Bocas and Jaina) was the wild site with the greatest number of injured crocodiles 

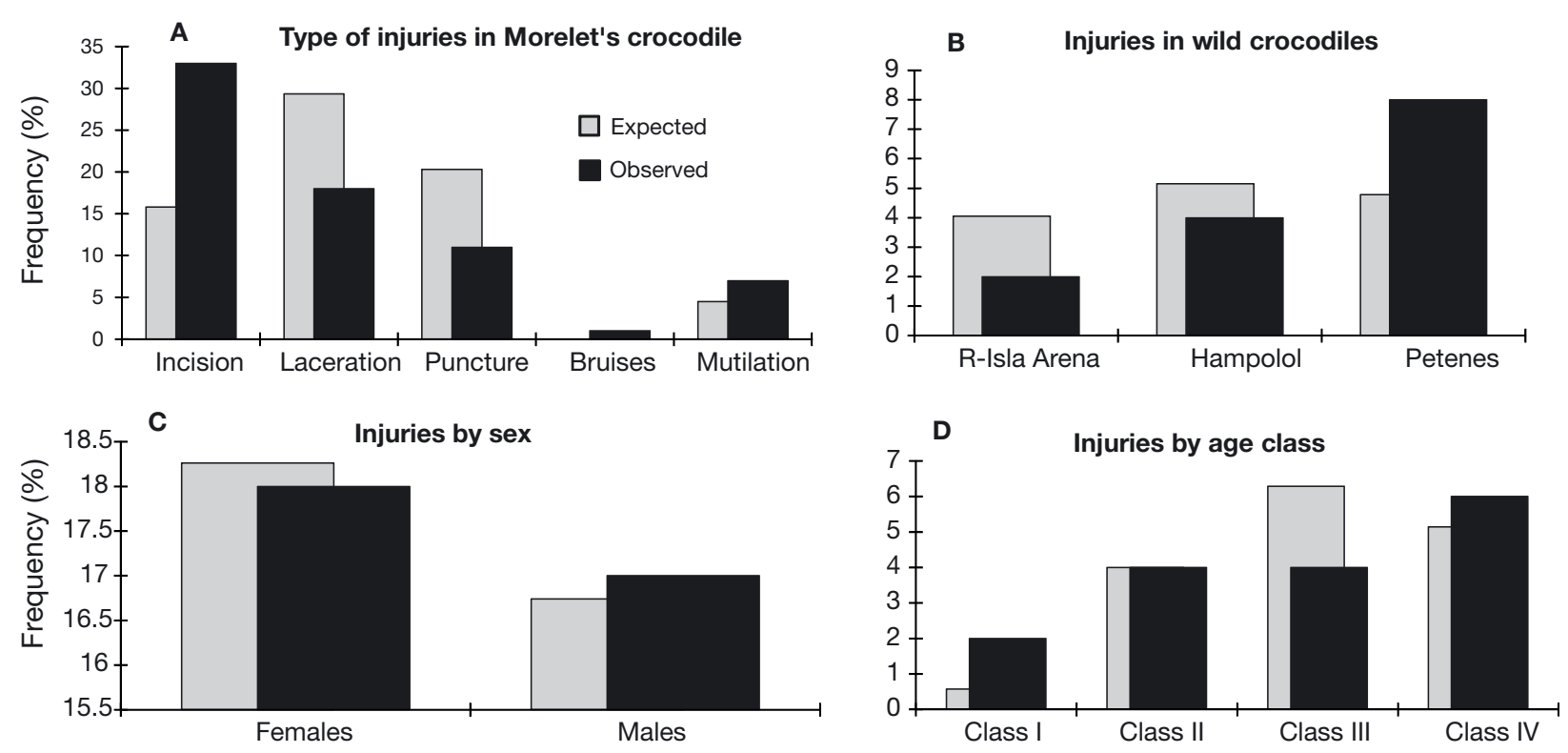

Fig. 2. Comparison of expected and observed external injuries in Crocodylus moreletii. (A) Type of injury in free-ranging and captive crocodiles $(\mathrm{n}=101 ; G=23.61, \mathrm{df}=4, \mathrm{p}<0.001) ;(\mathrm{B})$ injuries in free-ranging crocodiles per site $(\mathrm{n}=52 ; G=6.70, \mathrm{df}=$ $2, \mathrm{p}<0.05$ ); injuries $(\mathrm{C})$ by sex (females $\mathrm{n}=32$; males $\mathrm{n}=47 ; G=0.01$, df $=1, \mathrm{p}>0.05$ ) and (D) among size classes (Class I, $\mathrm{n}=26$; Class II, $\mathrm{n}=26$; Class III, $\mathrm{n}=27$; Class IV, $\mathrm{n}=24 ; G=1.40, \mathrm{df}=3, \mathrm{p}>0.05$ )

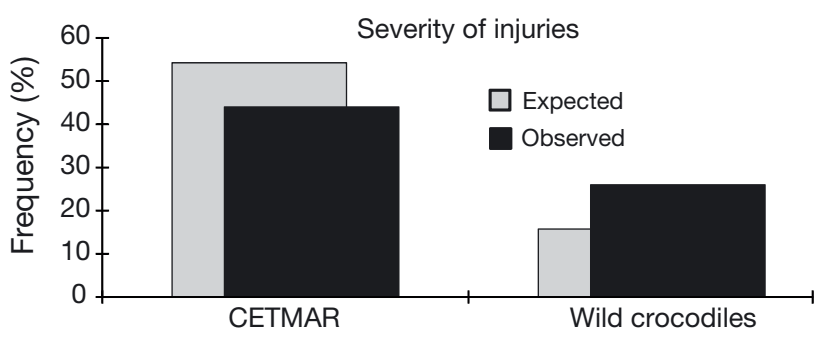

Fig. 3. Severity of expected and observed external injuries in captive and free-ranging Crocodylus moreletii. Captive Centro de Estudios Tecnológicos del Mar (CETMAR) crocodiles show the most severe injuries $(G=7.64, \mathrm{df}=1, \mathrm{p}<0.05)$

$(G=6.70, \mathrm{df}=2, \mathrm{p}<0.05)$. There was no statistical difference in the injuries observed between sexes $(G=$ $0.01, \mathrm{df}=1, \mathrm{p}>0.05)$ nor size classes $(G=1.40, \mathrm{df}=3$, $\mathrm{p}>0.05$ ) (Fig. 2). There was a statistical association in the severity of the lesions between wild and captive crocodiles, with the captive crocodiles presenting the deepest lesions ( $G=7.64$, df $=1$, p < 0.05) (Fig. 3).

Injuries caused by the nematode Paratrichosoma spp. were identified with no evidence of other external parasites. There is a statistical association between frequency of Paratrichosoma spp. lesions and the capture site $(G=22.32$, df $=1$, p < 0.05), with Petenes (free-ranging crocodiles) presenting the highest frequency of larva migrans cutanea lesions $(G=7.20, \mathrm{df}=2, \mathrm{p}<0.05)$ (Fig. 4). The highest num- ber of Paratrichosoma spp. skin lesions was found in the thoracic and abdominal region $(G=7.93$, $\mathrm{df}=2$, $\mathrm{p}<0.05)$.

\section{DISCUSSION}

The systematic study of injuries and lesions might be helpful to evaluate both the social interactions of a given population as well as the interaction of the individuals with the environment. This external evaluation of crocodile condition can provide information about the possible causes of mortality, or declining survival rates, which is required for adequate population management. From an economic point of view, the systematic evaluation of injuries can be helpful to evaluate the quality of hides for the skin trade (Webb $\&$ Smith 1987). Research on external injuries in crocodiles has been reported for the saltwater crocodile Crocodylus porosus (Webb \& Messel 1977), for the Australian freshwater crocodile C. johnstoni (Webb \& Manolis 1983), the New Guinea crocodile C. novaeguinae (Montague 1984), and more recently for the Orinoco crocodile C. intermedius (Webb \& Messel 1977, Webb \& Manolis 1983, Montague 1984, Seijas 2007).

The results from this study presents evidence about the differences in the prevalence of lesions in freeranging and captive Morelet's crocodiles. We observed 

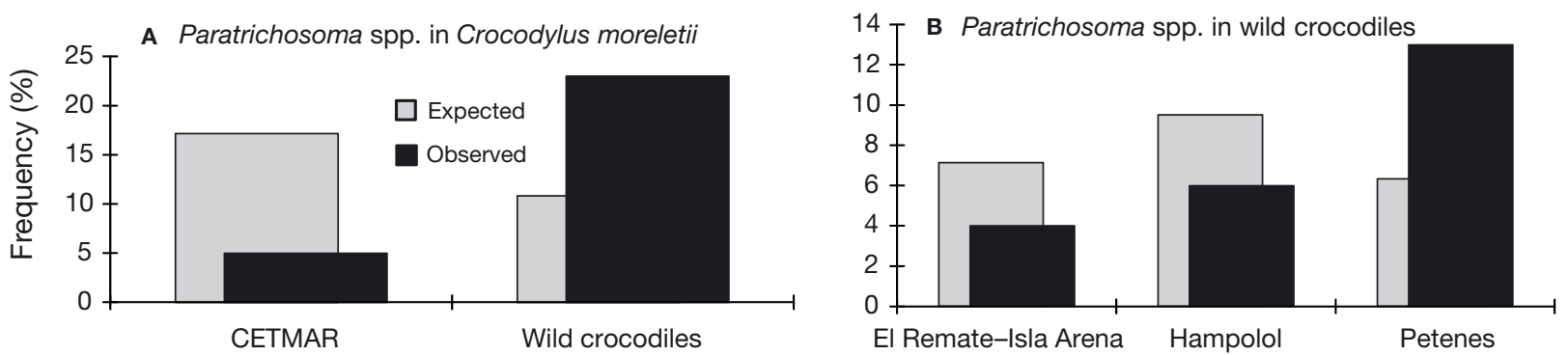

Fig. 4. Frequency of expected and observed Paratrichosoma spp. skin lesions in Crocodylus moreletii. (A) Captive Centro de Estudios Tecnológicos del Mar (CETMAR) and free-ranging (wild) crocodiles $(G=22.32$, df $=1, \mathrm{p}<0.05)$. (B) Wild sample sites $(G=7.20, \mathrm{df}=2, \mathrm{p}<0.05)$

aggressive behaviors among captive crocodiles during the data collection process. These agonistic interactions resulted in severe injuries in 3 crocodiles, which received immediate medical attention. An evident source of conflict is the crocodile densities in each enclosure. In the CETMAR, crowding of crocodiles was evident with densities exceeding 4 crocodiles per $\mathrm{m}^{2}$ in some enclosures with juveniles and subadults. Crowding might indeed predispose subadults to stress (Hutton \& Webb 1992, Seebacher \& Grigg 1997) and affect social interactions regardless of the fact that C. moreletii is considered highly tolerant to conspecifics (Lang 1987). An additional driver of agonistic interaction results from mixing crocodiles of different ages/sizes. Moderate crowding is not supposed to cause problems in captive crocodiles, as long as the animals are of similar sizes and ages (Bolton 1994); however, the sampled enclosures had both adult and subadult individuals.

Superficial lesions are common in captive crocodiles, in particular among juveniles and subadults (Huchzermeyer 2003). In captive C. niloticus, agonistic interactions are related to the size of the animal, the extent of crowding in the enclosures and fights for food (Huchzermeyer 2003), as well as variations in pool size (Bolton 1994). In CETMAR, skin lesions are not statistically associated with particular size classes. However, the adult class $(>150 \mathrm{~cm})$ had the largest proportion of injuries. These lesions are most likely the result of fights to establish dominant hierarchies (Huchzermeyer 2003), as dominance is often related to body size (Macdonald et al. 2000). The systematic evaluation of external injuries leads to recommendations for reducing densities and managing size classes of crocodiles, in order to reduce the likelihood of conflicts and improve captive rearing, especially if it is done for commercial purposes.

In regard to free-ranging crocodiles, the animals from the Petenes wetlands presented the largest frequency of injuries. Among them, adults and sub- adults were more frequently found with external lesions. This result concurs with Webb \& Messel (1977), who mentioned that $80 \%$ of C. porosus between 151 and $210 \mathrm{~cm}$ snout-vent length (adults) had some type of external lesion. Montague (1984) recorded lesions, abnormalities and external parasites in C. novaeguineae, with fewer lesions on the head. A similar pattern was documented in this study. Only 3 out of 32 lesions were found on the heads of $C$. moreletii. The prevalence of lesions was lower in small crocodiles (only 1 in Class I and 6 in Class II, out of a total of 32 lesions), in agreement with reports for C. novaeguineae (Montague 1984) and C. porosus (Webb \& Messel 1977). This could be explained by the high tolerance behaviour to conspecifics that C. moreletii exhibits (Lang 1987). A different pattern was found in the Orinoco crocodile $C$. intermedius. In this species, the largest frequency of lesions was found among the younger size classes, most likely the result of the attacks from piranhas on the younger crocodiles (Seijas 2007).

In this study, the nematode Paratrichosoma spp. was the only parasite recorded during the external examination of the crocodiles. Other external parasites that have been reported in the Morelet's crocodile are ticks and leeches (Rainwater et al. 2001). The presence of ticks in crocodiles might be related to the dispersal behavior of the animals during the dry season, when they wander in dry land. Crocodiles in this study were captured in the water and in places where water availability is year-round, and this might be the reason for the lack of ticks. Leeches were not found in this research. This is probably related to the salinity of the water where the crocodiles were captured. In a study in Mexico, García-Grajales \& Buentrostro-Silva (2011) found leeches of Placobdella spp. in C. acutus. This genera of leech inhabit freshwater wetlands and, according to Brantley \& Platt (1991), it does not tolerate saline environments. 

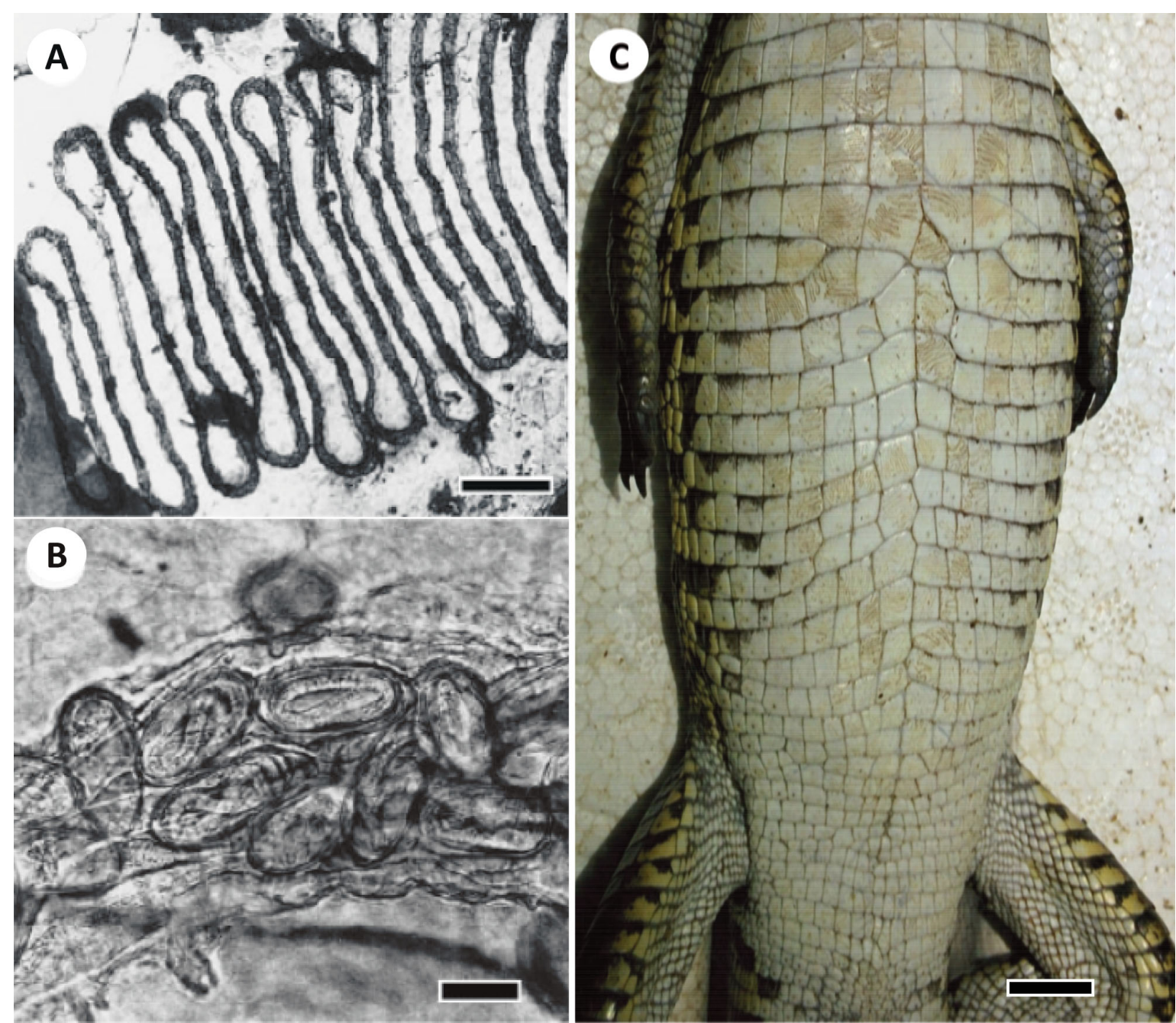

Fig. 5. Paratrichosoma spp. skin lesions in Crocodylus moreletii. (A) Zigzag tracks in the skin; (B) eggs observed inside the track lines (Morevec \& Vargas-Vázquez 1998); and (C) ventral view of Morelet's crocodiles with zigzag skin tracks (picture by Sergio E. Padilla). Scale bars: (A) $100 \mu m_{i}$ (B) $30 \mu m_{i}$ (C) $1 \mathrm{~cm}$

Paratrichosoma crocodylus is the nematode species that has been reported in several species of crocodilians both in the wild (Webb \& Messel 1977, Montague 1984, Seijas 2007) and in captivity (Fogging 1987, Buenviaje et al. 1998, Huchzermeyer 2003). P. recurvum was first described and reported in $C$. moreletii by Moravec \& Vargas-Vázquez (1998) from crocodiles captured in the Celestún lagoon, $50 \mathrm{~km}$ north of the area (same Petenes ecosystem) where this study took place. Thus, we assume that the larva migrans skin lesions (Fig. 5) recorded are probably pathognomonic of $P$. recurvum infections, but in the absence of a species identification assessment, we refer to this parasite as Paratrichosoma spp.

A lower prevalence of Paratrichosoma spp. skin lesions was recorded in captive crocodiles than in wild crocodiles. This might be related to the pond characteristics at CETMAR, which are cement made, restricting the presence of the nematode. A similar observation was made by Huchzermeyer (2003), who noted that only the crocodiles reared in earth ponds had the zigzag-shaped marks characteristic of Paratrichosoma spp. For this reason, a preventive action could be to avoid using earth ponds during the captive rearing of crocodiles.

Some animals in the farm have the zigzag-shaped larva migrans tracks in the belly. One possible reason for the presence of this parasite in CETMAR is that some crocodiles were captured in the wild for human security reasons and brought to captivity at CETMAR by officers of the Mexican Environmental Law Enforcement Agency (PROFEPA). This practice is common in Campeche, and captured crocodiles have been regularly taken to CETMAR for many years 
(J. Gómez-Duart, former CETMAR Director, pers. comm.). Buenviaje et al. (1998) reports a similar situation in captive $C$. porosus and their infestation with Paratrichosoma spp.

Crocodiles in the Petenes area were more infested with this nematode. This habitat is strongly influenced by sea tides and, therefore, abundant salt marshes can be found in the area. This is in contrast with what has been reported elsewhere, where the highest infestation rates were in animals living in rivers and other freshwater environments (Webb \& Messel 1977, Montague 1984). The Petenes coastal channels are connected with some freshwater springs (CONANP 2006). The crocodiles captured in Petenes might move from these springs to the salt marshes constantly in search of food or new territories, as suggested by Dever et al. (2002), who found genetic evidence of crocodile dispersal among localities in Belize. Also, the American crocodile C. acutus is able to disperse up to $35 \mathrm{~km}$ in similar habitats in Belize, moving constantly from salt marshes on the coast to inland freshwater lagoons (Platt et al. 1999b). It is important to point out that most of the animals captured in this study area, were subadults and adults; therefore, dispersal is likely to occur and could explain the infestation of Paratrichosoma spp. in C. moreletii. However, there is little information on the life cycle of Paratrichosoma sp. (Huchzermeyer 2003), so the relationship of its presence and water salinity is hypothetical.

Some management and conservation considerations arise from the findings of this study in regard to Paratrichosoma spp. infection patterns in the crocodiles of Campeche. The presence of Paratrichosoma spp. in a given crocodile hide may be an indication of its wild origin. This might be used as indirect indicator to detect skins from illegal hunting. We suggest that crocodile farmers construct ponds free of mud, and if they receive crocodiles captured in the wild, that they put and keep these animals in different enclosures. The high prevalence of Paratrichosoma spp. in relatively pristine habitats reported in this study suggest that parasitic relationships in crocodiles in minimally disturbed places (compared with more disturbed areas) might be higher and in a more natural (undisturbed) state. We hypothesize that anthropogenic influences might be affecting both parasite-host interactions and biodiversity assemblages, including crocodiles and this nematode parasite. Further studies on the relationships of parasitic nematodes and crocodiles in contrasting environments are needed to better understand these patterns and hypotheses.
Acknowledgements. We received support from CONACyT, El Colegio de la Frontera Sur (ECOSUR), Comisión Nacional de Áreas Naturales Protegidas (CONANP-RB Los Petenes), and the CETMAR, Campeche, Mexico. We thank Ernesto Perera, Mauricio González, Claudia Monzón, and Javier Gómez for field assistance, and Ramón Zetina for the map of the sample sites. We also thank 2 anonymous reviewers for providing valuable comments on the manuscript.

\section{LITERATURE CITED}

Alvarez del Toro M, Sigler L (2001) Los crocodylia de Mexico, 1st edn. IMERNAR PROFEPA, Mexico City

Beltrán E (1969) Crocodile conservation: two mexican projects. Biol Conserv 1:180-181

Bolton M (1994) La explotación del cocodrilo en cautividad. Guía de Conservación 22. FAO, Rome. www.fao.org (accessed 20 August 2010)

Brantley CG, Platt SG (1991) Salinity correlations of the leech Placobdella multilineata on alligators. Herpetol Rev 22:4-5

Buenviaje GN, Ladds PW, Martin Y (1998) Pathology of skin diseases in crocodiles. Aust Vet J 76:357-363

Cedeño-Vázquez JR, Ross JP, Calmé S (2006) Populations status and distribution of Crocodylus acutus and $C$. moreletii in southeastern Quintana Roo, México. Herpetol Nat Hist 10:17-30

CONABIO (2011) Programa de monitoreo del cocodrilo de pantano (Crocodylus moreletii) Mexico-Belice-Guatemala. CONABIO, SEMARNAT, Mexico City

CONANP (2006) Programa de conservación y manejo reserva de la biosfera Los Petenes. Comisión Nacional de Areas Naturales Protegidas, Mexico City

> Dever JA, Strauss RE, Rainwater TR, McMurry ST, Densmore LD III (2002) Genetic diversity, population subdivision, and gene flow in Morelet's crocodile (C. moreletii) from Belize, Central America. Copeia 2002(4):1078-1091

Domínguez-Laso J (2005) Determinación del estado de las poblaciones silvestres del cocodrilo de pantano $C$. moreletii en México y evaluación de su estatus en la CITES. Informe final del proyecto CS009. Comisión Nacional para el Conocimiento y Uso de la Biodiversidad (CONABIO), Mexico City

Dytham C (2006) Choosing and using statistics: a biologist's guide, 2nd edn. Blackwell Publishing, Oxford

Fogging CM (1987) Diseases and diseases control in crocodile farms in Zimbabwe. In: Webb GJW, Manolis SC, Whitehead PJ (eds) Wildlife management: crocodiles and alligators. Surrey Beatty and Sons, Chipping Norton, p 351-362

Fowler J, Cohen L, Jarvis P (1998) Practical statistics for field biology, 2nd edn. John Wiley \& Sons, Chichester

García-Grajales J, Buenrostro-Silva A (2011) Infestación y distribución corporal de sanguijuelas en el cocodrilo americano (Crocodylus acutus Cuvier 2807) (Reptilia: Crocodylidae) del estero de la Ventanilla, Oaxaca, Mexico. Acta Zool Mex 27:565-575

Garrick LD, Lang JW, Herzog HA Jr (1978) Social signals of adult American alligators. Bull Am Mus Nat Hist 160: 153-192

Huchzermeyer FW (2003) Crocodiles, biology, husbandry and diseases. CABI Publishing, London

Hutton JM, Webb GJW (1992) An introduction to the farming of crocodilians. In: Luxmoore RA (ed) Directory of 
crocodilian farming operations, 2nd edn. IUCN, Gland, p 1-39

INE (1999) Proyecto para la conservación y aprovechamiento sustentable de los crocodylia en México. SEMARNAP, Mexico City

Lang JW (1987) Crocodilian behaviour: implications for management. In: Webb GJW, Manolis SC, Whitehead PJ (eds) Wildlife management: crocodiles and alligators. Surrey Beatty and Sons, Chipping Norton, p 273-294

Macdonald DW, Stewart PD, Stopka P, Yamaguchi N (2000) Measuring the dynamics of mammalian societies: an ecologist's guide to ethological methods. In: Boitani L, Fuller TK (eds) Research techniques in animal ecology. Columbia University Press, New York, NY, p 332-388

McDonald JH (2014) Handbook of biological statistics, 3rd edn. Sparky House Publishing, Baltimore, MD, p 53-58

Montague JJ (1984) Abnormalities and injuries in New Guinea freshwater crocodile Crocodylus novaeguineae. J Herpetol 18:201-204

Moravec F, Vargas-Vázquez J (1998) First description of the male, and the redescription of the female of Paratrichosoma recurvum (Nematoda: Capillariidae), a skin-invading parasite of crocodiles in México. Parasitol Res 84: 499-504

Padilla SE, Perera-Trejo E (2010) Anotaciones sobre la percepción del cocodrilo de pantano C. moreletii, en las comunidades mayas aledañas a la reserva de la biosfera Los Petenes. Rev Lat Cons 1:83-90

Platt SG, Thorbjarnarson JB (2000) Population status and conservation of Morelet's crocodile C. moreletii in Northern Belize. Biol Conserv 96:13-20

Platt SG, Thorbjarnarson JB, Rainwater TR (1999a) Distribution of Morelet's crocodile (C. moreletii) in Southern Belize. Southwest Nat 44:395-398

Platt SG, Thorbjarnarson JB, Rainwater TR (1999b) Occurrence of the American crocodile in Lighthouse Atoll,

Editorial responsibility: Sven Klimpel,

Frankfurt, Germany
Belize. Caribb J Sci 35:316-318

> Rainwater TR, Platt SG, Robbins RG, Mcmurry ST (2001) Ticks from a Morelet's crocodile in Belize. J Wildl Dis 37 : 836-839

Seebacher F, Grigg GC (1997) Patterns of body temperature in wild freshwater crocodiles, Crocodylus johnstoni: thermoregulation versus thermoconformity, seasonal acclimatization, and the effect of social interactions. Copeia 1997:549-557

Seijas AE (2007) Heridas y parásitos en cocodrilos del Orinoco (Crocodylus intermedius) en un río altamente impactado por actividades humanas. Interciencia 32: $56-60$

Webb GJW, Messel H (1977) Abnormalities and injuries in the estuarine crocodile Crocodylus porosus. Aust Wildl Res 4:311-319

Webb GJW, Smith AMA (1987) Life history parameters, population dynamics and the management of crocodilians. In: Webb GJW, Manolis SC, Whitehead PJ (eds) Wildlife management: crocodiles and alligators. Surrey Beatty and Sons, Chipping Norton, p 199-210

- Webb GJW, Manolis SC (1983) Crocodylus johnstoni in the McKinley River area, N.T. V. Abnormalities and injuries. Aust Wildl Res 10:407-420

> Webb GJW, Manolis C, Sack GC (1984) Cloacal sexing of hatchling crocodiles. Aust Wildl Res 11:201-202

Woodward AR, Marion WR (1978) An evaluation of factors affecting night-light counts of alligators. Proc Annu Conf Southeast Assoc Fish and Wildl Agencies 32:291-302

Zamudio F, Bello-Baltazar E, Estrada-Lugo EIJ (2011) Integrando conocimientos mayas y científicos sobre el lagarto (C. moreletii) en el Ejido Xhazil Sur y anexos, Quintana Roo, Mexico. In: Bello-Baltazar E, EstradaLugo EIJ (Comps) Cultivar el territorio maya: conocimiento y organización social en el uso de la selva. El Colegio de la Frontera Sur, Mexico City, p 161-188

Submitted: May 11, 2015; Accepted: May 4, 2016

Proofs received from author(s): June 22, 2016 